\title{
PENGARUH LATIHAN LARI KIJANG DAN LARI GAWANG TERHADAP KEMAMPUAN LOMPAT JAUH DITINJAU DARI DAYA LEDAK OTOT TUNGKAI PADA SISWA KELAS VIII SMP NEGERI 4 GOLEWA
}

\author{
Josep Marsianus Rewo \\ Dosen Program Studi Pendidikan IPA STKIP Citra Bakti \\ e-mail: josmarrewosiu@gmail.com.
}

\begin{abstract}
Abstrak
Penelitian ini merupakan kuasi eksperimen yang menggunakan non-equivalent control group design. Data yang dikumpulkan dalam penelitian ini adalah tes unjuk kerja lompat jauh siswa. Penelitian ini bertujuan untuk mengetahui dan menganalisis pengaruh latihan lari kijang dan lari gawang untuk meningkatkan kemampuan lompat jauh siswa di tinjau dari daya ledak otot tungkai. Sampel penelitian berjumlah 84 orang siswa kelas VIII yang dipilih dengan teknik random sampling. Data dikumpulkan dengan tes, kemudian dianalisis dengan analisis varian (Anava dua jalur). Hasil penelitian menemukan sebagai berikut. (1) terdapat perbedaan kemampuan lompat jauh antara siswa yang mengikuti model latihan lari kijang dengan siswa yang mengikuti model latihan lari gawang $\left(F_{\text {hitung }}=4,06>F_{\text {tabel }(\alpha=5 \%)}\right)=$ 4,00, signifikan). (2) Terdapat pengaruh interaksi antara model latihan dengan daya ledak otot tungkai terhadap lompat jauh $\left(F_{\text {hitung }}=23,39>F_{\text {tabel }(\alpha=5 \%)}=4,00\right.$, signifikan). (3) Tidak terdapat perbedaan lompat jauh antara siswa yang mengikuti latihan lari kijang dan lari gawang untuk siswa yang memiliki daya ledak otot tungkai tinggi $\left(Q_{\text {hitung }}=16,43>Q_{\text {tabel }}=4,00\right.$ signifikan $)$. (4) Terdapat perbedaan lompat jauh antara siswa yang mengikuti model latihan lari kijang dan lari gawang untuk siswa yang memiliki daya ledak otot tungkai rendah ( $Q_{\text {hitung }}=5,919>Q_{\text {tabel }}=4,00$ signifikan $)$.
\end{abstract}

\section{Abstract}

This study was quasi experiment used non-equivalent control design. The data collected in this study was the student performance test of long jump. This study aims to determine and analyze the influence of the practice of lari kijang and lari gawang to improve students' long jump ability in review of the explosive muscle limb power. The sample of the study was 84 students of grade VIII chosen by random sampling technique. The data was collected by test then analyzed with variant analysis (ANAVA) two ways) and t-test. The result of the study showed that: (1) There is a difference in long jump ability between students who follow the model of lari kijang training with students who follow the model of lari gawang $\left(F_{\text {hitung }}=4,06\right.$ $\left.>F_{\text {tabel }(\alpha=5 \%)}\right)=4,00$, significant) (2) There is an interaction effect between the exercise model and the explosive muscle limb power against the long jump ( $F_{\text {hitung }}=$ $23,39>F_{\text {tabel }(\alpha=5 \%)}=4,00$, significant). (3) There is no difference in long jump between students who follow lari kijang and lari gawang for students who have high limb muscle explosive power $\left(Q_{\text {hitung }}=16,43>Q_{\text {tabel }}=4,00\right.$ significant) (4) There is a long jump difference between students who follow the model of lari kijang and lari gawang for students who have low limb muscle explosiveness $\left(Q_{\text {hitung }}=5,919>>Q_{\text {tabel }}=4,00\right.$ significant).

Kata-kata kunci: Latihan Lari Kijang dan Lari Gawang, Lompat Jauh, Daya Ledak Otot Tungkai 


\section{PENDAHULUAN}

Atletik yang meliputi Jalan, Lari, Lompat dan Lempar boleh dikatakan cabang olah raga yang paling tua, sama tuanya dengan manusia pertama di dunia, sebab manusia pertama didunia sudah harus berjalan, lari, lompat dan lempar untuk mempertahankan hidupnya. Dalam contoh tersebut manusia telah mempergunakan kecakapan lari, lompat dan lempar untuk mempertahankan diri dari terkaman binatang buas. Lari, lompat dan lempar adalah suatu bentuk gerakan yang tidak ternilai artinya bagi hidup manusia. Gerakan itu semuanya ada dalam olahraga atletik. Bahkan gerakan-gerakan tersebut menjadi dasar dan intisari dari semua cabang olahraga. Itulah sebabnya atletik disebut sebagai "Ibu Olahraga". Meskipun gerakan dasar ini telah dikenal sejak adanya manusia, tetapi perlombaan atletik yang telah dilaksanakan dalam catatan sejarah, baru terjadi pada jaman purba, sekitar 1000 tahun sebelum masehi.

Lompat jauh sebagai salah satu cabang atletik memang tidak tertulis secara autentik sejak kapan manusia melakukan lompat jauh sebagai prestasi atau untuk kebugaran. Lompat jauh bertujuan melakukan lompatan sejauh-jauhnya menuju titik yang telah ditentukan (Wiarto, 2013:32). Dalam cabang olahraga, lompat jauh merupakan salah satu nomor lomba atletik. Lompat jauh terdapat empat komponen utama yaitu lari awalan, tumpuan/tolakan, sikap diudara/melayang dan mendarat.

Olahraga tumbuh dan berkembang dalam berbagai bentuk dengan berbagai cara pelaksanaan, pengorganisasian dan tujuan yang berbeda-beda sesuai dengan pelaksanaannya masing-masing. Ada empat dimensi kegiatan olahraga yakni 1) olahraga rekreasi yang menekankan tercapainya kesehatan jasmani dan rohani, 2) olahraga pendidikan yang menekankan aspek pendidikan, dimana olahraga merupakan alat untuk mencapai tujuan pendidikan, 3) olahraga kompetitif yang menekankan kegiatan kompetisi dan pencapaian prestasi, dan 4) olahraga rehabilitasi yang menekankan kegiatan pemulihan dari sakit atau cidera. Olahraga pendidikan diperlukan berbagai pertimbangan dan perhitungan mulai dari perencanaan, 
pelaksanaan dan evaluasi dalam proses pelatihan. Tujuan pelatihan dalam olahraga pendidikan adalah untuk menguasai standar kompetensi dan kompetensi dasar serta mengembangkan kemampuan biomotor (kekuatan, kecepatan, power kelentukan dan daya tahan) khususnya menyangkut tugas gerak dalam proses pendidikan jasmani olahraga dan kesehatan dan olahraga. Salah satunya adalah usaha meningkatkan penguasaan keterampilan gerak siswa dalam berbagai aktivitas olahraga yang terdapat dalam kurikulum karena salah satu tujuan khusus pendidikan jasmani olahraga dan kesehatan pada semua jenjang pendidikan adalah pencapaian standar kompetensi dan kompetensi dasar secara tuntas.

Dalam pendidikan jasmani pendidik dituntut mampu mengajarkan berbagai gerak dasar, teknik, dan strategi permainan dan olahraga sehingga siswa memperoleh berbagai pengalaman untuk mengungkapkan kesan pribadi yang menyenangkan, kreatif, inovatif, meningkatkan dan memelihara kebugaran serta pemahaman terhadap gerak manusia (Depdiknas, 2003:2).
Berbagai gejala atau fenomena yang tampak dan berkaitan dengan rendahnya prestasi belajar dalam pendidikan jasmani olahraga dan kesehatan sesuai dengan pengamatan yang dilakukan oleh peneliti pada hari rabu, 25 april yaitu rendahnya tingkat pemahaman guru tentang kurikulum tingkat satuan pendidikan yang diterapkan, kurangnya kemampuan guru mengenai metode kepelatihan dalam olahraga dan keterampilan yang memadai untuk mengoptimalkan prestasi siswa serta memanfaatkan sarana dan prasarana pelatihan yang tersedia, siswa cenderung hanya memanfaatkan waktu yang ada disekolah ketimbang memanfaatkan waktu senggang untuk berlatih olahraga, orang tua siswa masih belum maksimal dalam memotivasi anaknya untuk lebih berprestasi di bidang olahraga. Masalah atau problematika yang sering timbul baik secara langsung maupun tidak berdampak terhadap guru pendidikan jasmani saat berganti peran menjadi seorang pelatih cabang olahraga prestasi, misalkan pada saat melakukan pelatihan cabang olahraga atletik lompat jauh, kurangnya minat peserta didik terhadap olahraga atletik khususnya lompat jauh, diantaranya 
metode latihan yang kurang variasi dan kurang menariknya penyajian aktivitas cabang olahraga ini oleh para pengajar di sekolah dan juga para pelatih dasar dalam klub olahraga yang menyampaikan materi tentang lompat jauh. Hal ini tentunya membutuhkan kajian ulang tentang metode-metode dalam pengajaran dan pelatihan atletik. Kurangnya minat merupakan salah satu penyebab mundurnya prestasi, disamping variasi latihan yang kurang, faktor lain yang menyebabkan prestasi seorang lompat jauh kurang maksimal adalah masih rendahnya pengetahuan pendidik atau pelatih terhadap bentuk latihan dan prinsip-prinsip dalam berlatih dan melatih.

Berdasarkan latar belakang di atas muncul beberapa permasalahan yang memerlukan solusi lebih lanjut. Beberapa masalah yang berkaitan dengan judul penelitian tersebut adalah sebagai berikut. a. Kurang nya variasi latihan yang dilakukan oleh guru/pelatih cabang olahraga prestasi khususnya lompat jauh. b. Kurangnya pemahaman guru pendidikan jasmani terhadap metode melatih dan prinsp melatih pada saat dituntut berganti peran menjadi seorang pelatih olahraga prestasi. c. Guru atau pelatih kurang memahami komponen biomotor pendukung dari cabang olahraga prestasi khususnya lompat jauh. d. Kurang tepatnya memilih bentuk latihan yang diberikan dengan komponen biomotor pendukung lompat jauh. e. Pengaruh lari kijang dan lari gawang masih belum diketahui manfaatnya sehingga dalam penerapannya masih khurang mendapatkan perhatian yang maksimal.

Menyadari banyaknya faktorfaktor yang berpengaruh terhadap prestasi belajar siswa dalam pemebelajaran olahraga, khususnya lompat jauh serta kompleks dan banyaknya permasalahan yang teridentifikasi, maka dalam penelitian ini akan difokuskan pada pengkajian dan pengujian terhadap pengaruh latihan lari kijang dan lari gawang terhadap lompat jauh ditinjau dari daya ledak otot tungkai siswa. Siswa yang dilibatkan dalam penelitian ini adalah siswa kelas VIII SMP Negeri 4 Golewa. Variabel terikat dalam penelitian ini adalah lompat jauh.

Dari paparan latar belakang di atas, maka rumusan masalah dapat dirumuskan sebagai berikut. 1) Apakah terdapat perbedaaan prestasi lompat jauh antara siswa yang 
mengikuti pelatihan lari kijang dengan siswa yang mengikuti pelatihan lari gawang? 2) Apakah terdapat pengaruh interaksi antara pelatihan lari kijang dan lari gawang dengan daya ledak otot tungkai terhadap prestasi lompat jauh? 3) Pada siswa yang memiliki daya ledak otot tungkai tinggiapakah terdapat perbedaan prestasi lompat jauh antara siswa yang mengikuti pelatihan lari kijang dengan lari gawang? 4) Pada siswa yang memiliki daya ledak otot tungkai rendahapakah terdapat perbedaan prestasi lompat jauh antara siswa yang mengikuti pelatihan lari kijang dengan lari gawang?

Tujuan yang ingin dicapai dalam riset ini adalah. 1) Untuk mengetahui perbedaaan kemampuan prestasi lompat jauh antara siswa yang mengikuti pelatihan lari kijang dengan siswa yang mengikuti pelatihan lari gawang? 2) Untuk mengetahui pengaruh interaksi antara pelatihan lari kijang dan lari gawang dengan daya ledak otot tungkai terhadap prestasi lompat jauh? 3) Untuk mengetahui perbedaan prestasi lompat jauh antara siswa yang mengikuti pelatihan lari kijang dan lari gawang pada siswa yang memiliki daya ledak otot tungkai tinggi? 4) Untuk mengetahui perbedaan prestasi lompat jauh antara siswa yang mengikuti pelatihan lari kijang dan lari gawang pada siswa yang memiliki daya ledak otot tungkai rendah?

\section{METODE PENELITIAN}

Penelitian ini akan dilaksanakan pada siswa kelas VIII SMP Negeri 4 Golewa. Pada dasarnya penelitian ini bertujuan untuk mengetahui pengaruh latihan lari kijang dan lari gawang terhadap kemapuan lompat jauh ditinjau dari daya ledak otot tungkai. Latihan akan dilakukan terhadap variabel bebas yaitu lari kijang dan lari gawang sebagai variabel kontrol, serta yang menjadi variabel terikat adalah lompat jauh dengan variabel moderator daya ledak otot tungkai yang mana daya ledak otot tungkai terdiri atas dua yaitu daya ledak otot tungkai tinggi dan daya ledak otot tungkai rendah. Berpegang pada prinsip-prinsip latihan, maka pemberian treatmen lari kijang dan lari gawang akan dilakukan dengan jarak 30 meter dengan 5 repetisi, dalam 3 set dengan istirahat antar set 120 detik serta dengan durasi seminggu 3 kali selama dua minggu. Pree-Test dilakukan setelah ditentukannya kelas/kelompok eksperimen dan kelompok kontrol, serta satu kali 
pertemuan untuk tes pengambilan prestasi (Post-Test). Sehubungan akan dilakukan sebuah riset terhadap hal tersebut, jenis desain penelitian yang akan digunakan adalah adalah Quasi Exsperiment: Non-Equivalent Control Group Design.

Di dalam desain ini observasi dilakukan sebanyak satu kali yaitu sesudah eksperimen baik terhadap kelompok eksperimen maupun kelompok kontrol. Rancangan analisis data yang digunakan adalah dengan factorial $2 \times 2$ atau anavadua jalur.

Faktor pemilihan adalah variabel moderator daya ledak otot tungkai. Pemilihan dibagi dua tingkatan yaitu daya ledak otot tungkai tinggi dan daya ledak otot tungkai rendah, nantinya dalam pelaksanaan eksperimen atara siswa yang memiliki daya ledak otot tungkai tinggi dan rendah tidak dipisahkan secara nyata.

Populasi merupakan sejumlah kasus atau sejumlah individu (yang sifatnya bisa infinite atau definite) yang memiliki karakteristik tertentu, maka suatu penelitian yang meneliti seluruh individu yang terdapat dalam wilayah penelitian dapat disebut dengan studi sensus (census study). (Dantes, 2012:37). Menurut Koyan (2012:30) populasi adalah himpunan dari unsur- unsur sejenis, unsur sejenis itu dapat berupa manusia, hewan, tumbuhtumbuhan, benda, zat cair, peristiwa dan sejenisnya. Dalam penelitian ini yang menjadi populasi adalah siswa kelas VIII SMP Negeri 4 Golewa. Dari populasi tersebut nantinya akan diambil sampel penelitian berdasarkan data tes lompat tegak, untuk mengukur daya ledak otot tungkai tinggi dan rendah. Untuk menentukan tinggi rendahnya daya ledak otot tungkai dengan melakukan tes vertical jump terlebih dahulu. Selanjutnya hasil lompatan setiap subyek dikonversi kedalam norma tes lompat tegak (vertical jump test).

Dalam penelitian ini diambil empat kelas sampel, dua kelas ditugaskan sebagai kelompok eksperimen, dan dua kelas ditugaskan sebagai kelompok kontrol. Untuk menentukan kelas sebagai kelompok eksperimen dan kelompok kontrol dilakukan secara random. Dimana jumlah sampel diambil 80 orang dengan prosedur pembagian sampel sebagai berikut: 40 orang siswa yang mengikuti latihan lari kijang dan 40 orang siswa lainnya mengikuti latihan lari gawang. Dari 40 orang siswa di setiap perlakuan latihan lari kijang dan lari gawang dibagi lagi yaitu 20 orang 
siswa yang memiliki daya ledak otot tungkai tinggi dan 20 orang siswa lainnya yang memiliki daya ledak otot tungkai rendah. Sejalan dengan itu, suatu pendapat menyatakan bahwa random sampling (acak) adalah sebuah proses sampling yang dilakukan sedemikian rupa sehingga setiap satuan sampling yang ada dalam populasi mempunyai peluang yang sama untuk dipilih ke dalam sampel (Somantri, 2006:71). Dalam suatu penelitian eksperimen, Sutrisno Hadi (1982:437) membedakan variabel menjadi dua yaitu (1) variabel eksperimen atau treatment variable yaitu kondisi yang hendak diselidiki bagaiman pegaruhnya terhadap gejala atau behaviour variable, (2) variabel non eksperimental yaitu variabel yang dikontrol dalam arti baik untuk kelompok eksperimental. Sedangkan Suharsimi Arikunto (1998:101) membedakan variabel menjadi dua yaitu variabel yang mempengaruhi disebut variabel penyebab, variabel bebas atau independent variabel $(X)$, dan variabel akhibat yang disebut variabel tak bebas, variabel tergantung, variabel terikat, atau dependent variabel dan variabel akhibat yang disebut variabel tak bebas, variabel tergantung, variabel terikat, atau dependent variabel (Y).Sugiyono (2006:2-4) dalam buku Statistik untuk Penelitian mengatakan bahwa variabel bebas (variabel independen) adalah variabel yang menjadi sebab timbulnya atau berubahnya variabel terikat (variabel defenden), variabel denvenden adalah variabel yang mempengaruhi atau menjadi akhibat karena adanya variabel bebas. Variabel moderator adalah variabel yang mempengaruhi (memperkuat atau memperlemah) hubungan antara variabel bebas dengan variabel terikat.

\section{HASIL DAN PEMBAHASAN}

Penelitian ini merupakan penelitian eksperimen semu dengan desain posttes-only control group design dan dengan desainvaktorian 2 $x$ 2. Variabel bebas dalam penelitian ini adalah model latihan yang terdiri atas model latihan lari gawang yang dikenakan pada kelompok eksperimen, dan model latihan lari kijang pada kelompok kontrol. Panjang tungkai merupakan variabel moderator yang terdiri dari tungkai panjang dan tungkai pendek.Variabel terikat pada penelitian ini adalah kemampuan lompat jauh.

Berdasarkan hasil pengujian hipotesis pertama hasil analisis 
menggunakan Anava diperoleh harga $F_{\text {hitung }}$ sebesar 4,06 dengan $F_{\text {tabel }} 4,00$ (signifikan). Maka dapat disimpulkan bahwa terbukti terdapat perbedaan kemampuan prestasi lompat jauh antara siswa yang mengikuti model latihan lari kijang dengan siswa yang mengikuti model latihan gawang, dimana rata-rata peningkatan kemampuan lari kijang adalah sebesar 329,30 lebih tinggi dibandingkan dengan dengan yang mengikuti lari gawang sebesar 350,78. Hasil tersebut (tingkat signifikan untuk harga $F_{\text {hitung }}$ kurang dari 0,05). Jadi dalam perbandingan antara siswa yang mengikuti model latihan lari kijang dengan siswa mengikuti model latihan gawang berpengaruh, namun pengaruh lebih tinggi adalah kelompok siswa yang diberikan model latihan gawang dibanding lari kijang. Berdasarkakn teori yang ada dan hasil pengamatan gerak lari gawang menghasilkan lompatan yang jauh. Untuk pelatihan atau guru pendidikan jasmani dalam menerapkan latihan untuk meningkatkank prestasi lompat jauh dapat melihat keunggulan salah satu dari program latihan tersebut tetap melihat atau berpedoman pada prinsip-prinsip melatih.
Hasil analisis menggunakan anava diperoleh harga $F$ 16,43 degan $F$ tabel 4,00. Maka berdasarkan hasil analilsis ternyata terbukti terdapat pengaruh interaksi antara latihan lari kijang dengan lari gawang terhadap daya ledak otot tungkai tinggi dimana rata-rata (mean) pencapaian prestasi lompat jauh adalah sebesar 392,70dengan standar deviasi sebesar 61,398

Jadi dalam proses latihan prestasi lompat jauh komponen daya ledak otot tungkai perlu mendapat perhatian dan lebih sistematis, sehingga menghasilkan prestasi lompat jauh yang lebih baik.

Berdasarkan hasil perhitungan analisis data terbukti bahwa hipotesis alternatif $\left(\mathrm{H}_{1}\right)$ yang menyatakan terdapat perbedaan prestasi lompat jauh antara siswa yang mengikuti latihan lari kijang dan lari gawang, pada siswa yang memiliki daya ledak otot tungkai tinggi, diterima. Maka terdapat perbedaan prestasi lompat jauh antara siswa yang mengikuti model latihan lari kijang untuk siswa yang memiliki daya ledak otot tungkai tinggi dengan model latihan lari gawang untuk siswa yang memiliki daya ledak otot tungkai tinggi. 
Hasil analisis menggunakan Anava yang dilanjutkan dengan uji Tukey dengan menggunakan SPSS 16 diperoleh harga $Q$ hitung sebesar 16,43 $Q_{\text {tabel}} 4,00$ Hal ini menunjukkan bahwa pasangan kelompok $A_{1} B_{2}$ dengan $A_{2} B_{2}$ memiliki perbedaan yang signifikan sehingga membuktikan bahwa Hipotesis nol (Ho) yang menyatakan "terdapat perbedaan prestasi lompat jauh antara siswa yang mengikuti latihan lari kijang dan lari gawang pada siswa yang memiliki daya ledak otot tungkai rendah”, diterima kebenarannya. Ini artinya hipotesis alternatif $\left(\mathrm{H}_{1}\right)$ yang menyatakan terdapat perbedaan prestasi lompat jauh antara siswa yang mengikuti latihan lari kijang dan lari gawang, pada siswa yang memiliki daya ledak otot tungkai rendah, diterima.

Artinya untuk siswa yang memiliki daya ledak otot tungkai tinggiakan memberikan dampak perbedaan prestasi lompat jauhlebih baik dilatih dengan lari gawang dibandingkan dengan yang dilatih dengan lari kijang. Berdasarkan data tersebut ternyata siswa yang diberikan program latihan lari kijang dan lari gawang yang memiliki daya ledak otot tungkai tinggi memberikan manfaat yang bermakna terhadap peningkatan prestasi prestasi lompat jauh. Jadi berdasarkan hal tersebut seorang pelatih olahraga kemampuan agar sebelum melakukan program latihan/atau memilih altet untuk dibina menjadi altet prestasi lompat jauh sangat penting juga melakukan pengukuran daya ledak otot tungkai, sehingga calon atlet yang dibina diketahui apakah memiliki daya ledak otot tungkai tinggi atau rendah.

\section{PENUTUP}

Penelitian ini didasari rendahnya lompatan siswa khususnya terhadap prestasi lompat jauh. Hasil prestasi lompat jauh ini, tentunya tidak terlepas dari beberapa faktor pendukung. Faktor utama yang dapat memacu perkembangan prestasi olahraga terutama adanya peningkatan kualitas latihan dan pembinaan olahraga. Peningkatan kualitas latihan dan pembinaan olahraga tersebut dapat dicapai dengan penerapan berbagai disiplin ilmu dan teknologi yang terkait dengan latihan dan pembinaan olahraga. Dalam peningkatan kualitas jasmani maupun pretasi olahraga tidak terlepas dari proses pendidikan jasmaniyang dilakukan secara dini, yaitu dari pendidikan anak usia dini maupun 
tingkat lanjut pada jenjang perguruan tinggi. Dalam pendidikan jasmani pendidik dituntut mampu mengajarkan berbagai gerak dasar, teknik, dan strategi permainan dan olahraga sehingga siswa memperoleh berbagai pengalaman untuk mengungkapkan kesan pribadi yang menyenangkan, kreatif,inovatif, meningkatkan dan memelihara kebugaran serta pemahaman terhadap gerak manusia. Untuk dapat melompat dengan maksimal ada beberapa aspek biomotorik yang hams dikembangkan melalui latihan, aspek-aspek tersebut adalah kekuatan, daya ledak/exsplosif power, kecepatan, daya tahan, kelentukan, dan koordinasi. Kecepatan merupakan komponen biomotorik yang sangat penting dibutuhkan dalam olahraga, sebab kebanyakan atlet lompat, beraksi atau berubah arah dengan cepat.

Latihan daya ledak sangat penting untuk diberikan pada atlet lompat khususnya prestasi lompat jauh, karena untuk menjadi juara dalam lomba prestasi lompat jauh tersebut, diperlukan tolakan yang maksimaldalam melompat. Untuk dapat memproleh hasil lompatan yang jauh didukung oleh program dan bentuk latihan yang tepat. Untuk dapat meningkatkan tenaga kaki (power) dan akselerasi lari, banyak sekali cara untuk melatihnya, antara lain; latihan dengan lari kijang, langkah melambung (lari gawang), lompat kelinci, prestasi lompat jauh, kombinasi lompat dan melambung melintasi rintangan rendah, berlari dengan lutut tinggi ke depan dan kebelakang, latihan ini dapat meningkatkan prestasi lompat jauh. Untuk melatih meningkatkan kernampuan prestasi lompat jauh peneliti menerapkan latihan lari gawang dan lari kijang terhadap kernampuan prestasi lompat jauh ditinjau dari daya ledak otot tungkai. Dimana daya ledak otot tungkai dibagi menjadi dua yaitu daya ledak otot tungkaitinggi dan daya ledak otot tungkai rendah.

Penelitian ini merupakan penelitian eksperimen semu dengan desain posttes-only control group design dan dengan desainvaktorian $2 \times 2$. Variabel bebas dalam penelitian ini adalah model latihan yang terdiri atas modellatihan lari gawang yang dikenakan pada kelompok eksperimen, dan model latihan lari kijang pada kelompok kontrol. Daya ledak otot tungkai merupakan variabel moderator yang terdiri dari daya ledak 
otot tungkai tinggi dan daya ledak otot tungkai rendah. Variabel terikat pada penelitian ini adalah prestasi lompat jauh.

Subjek penelitian adalah siswa Kelas VIII SMP Negeri 4 Golewa Tahun. Sampel penelitian adalah sebanyak 80 orang yang dipilih dengan teknik random sampling. Penelitian ini menggunakan beberapa instrumen pengumpulan data. Data terdiri atas pengukuran panjang tungkai, dan prestasi lompat jauh. Sebelum data prestasi lompat jauh diolah secara statistik diuji normalitas terlebih dahulu. Setelah data diuji normalitasnya dan memenuhi syarat maka data akan diolah secara statistik. Untuk pengujian hipotesis menggunkan analisis anava dua jalur dan tukey test, sebelum data diuji secara hipotesis, terlebih dahulu data dikumpulkan dan dianalisis normalitas dan homogenitasnya.

Data yang diperoleh dari prestasi lompat jauh selanjutnya ditabulasi menjadi delapan kelompok data, kedelapan kelompok data tersebut adalah sebagai berikut: (1) Prestasi lompat jauh kelompok perlakuan lari kijang pada siswa yang memiliki daya ledak otot tungkaitinggi $\left(\mathrm{YA}_{1} \mathrm{~B}_{1}\right)$ memiliki nilai statistik 0,177 dengan taraf signifikansi 0,100 $(p>0,05)$. (2) Prestasi lompat jauh kelompok perlakuan lari kijang pada siswa yang memiliki daya ledak otot tungkairendah $\left(\mathrm{YA}_{1} \mathrm{~B}_{2}\right)$ memiliki nilai statistik 0,118 dengan taraf signifikansi 0,200 (p>0,05). (3) Prestasi lompat jauh kelompok perlakuan lari gawang pada siswa yang memilikidaya ledak otot tungkai tinggi $\left(\mathrm{YA}_{2} \mathrm{~B}_{1}\right)$ memiliki nilai statistik 0,179 dengan taraf signifikansi $0,093 \quad(p>0,05)$.

Peningkatan prestasi lompat jauh kelompok perlakuan lari gawang pada siswa yang memiliki daya ledak otot tungkairendah $\left(\mathrm{YA}_{2} \mathrm{~B}_{2}\right)$ memilikinilai statistik 0,125 dengan taraf signifikansi 0,200 (p>0,05). (5) Prestasi lompat jauh kelompok perlakuan lari kijang $\left(Y A_{I}\right)$ memiliki nilai statistik 0,135 dengan taraf signifikansi 0,064 $(p>0,05)$. (6) Prestasi lompat jauh kelompok perlakuan lari gawang $\left(\mathrm{YA}_{2}\right)$ memiliki nilai statistik 0,137 dengan taraf signifikansi $0,057 \quad(p>0,05) . \quad(7)$ Prestasi lompat jauh kelompok siswa yang memiliki daya ledak otot tungkai tinggi $\left(\mathrm{YB}_{\mathrm{I}}\right)$ memiliki nilai statistik 0,130 dengan taraf signifikansi 0,085 (p>0,05). (8) Prestasi lompat jauh kelompok siswa yang memiliki daya ledak otot tungkai rendah $\left(\mathrm{YB}_{2}\right)$ 
memiliki nilai statistik 0,063 dengan taraf signifikansi 0,200 ( $p>0,05)$.

Berdasarkan hasil analisis diperoleh tingkat signifikansi untuk statistik hitung pada variabel peningkatan lari lebih besar dari 0,05. Hasil tersebut memmjukan bahwa variabel yang diuji sebaran datanya adalah normal.Berdasarkan hasil analisis data penelitian yang telah disajikan di atas, ada beberapa temuan dalam penelitian ini: (1) Hasil perhitungan ANAVA dua jalur menunjukkan bahwa, $F_{\text {hitung }}=16,43>$ $\operatorname{Ftab}\left({ }_{\mathrm{a}}=5 \%\right)=4,00$ (signifikan) ini berarti hipotesis nol $(\mathrm{Ho})$ yang menyatakan bahwa prestasi lompat jauh pada siswa yang mengikuti model latihan lari kijang sama dengan siswa yang mengikuti model latihan lari gawang, di tolak, hipotesis alternatif $(\mathrm{Hi})$ yang menyatakan bahwa prestasi lompat jauh pada siswa yang mengikuti model latihan lari kijang tidak sama dengan prestasi lompat jauh pada siswa yang mengikuti model latihan lari gawang diterima. Hal ini menunjukkan bahwa terdapat perbedaan prestasi lompat jauh antara siswa yang mengikuti latihan lari kijang dengan siswa yang mengikuti model latihan lari gawang. Hasil anasilisis menunjukkan bahwa kelompok siswa yang mengikuti model latihan lari kijang. (Kelompok $A_{1}$ ) ratarata memiliki peningkatan prestasi lompat jauh siswa yang menggunakan latihan lari kijang 329,30 dengan lompatan maksimal 485, sedangkan siswa yang mengikuti model latihan lari gawang $\left(A_{2}\right)$ rata-rata memiliki peningkatan prestasi lompat jauh sebesar 350,78, dengan lompatan maksimal 486 meter. (2) Hasil perhitungan ANAVA dua jalur menunjukkan bahwa $F A B=16,43>$ $\operatorname{Ftab}(a=5 \%)=4,00$ (signifikan) maka $\mathrm{HO}$ ditolak dan $\mathrm{H}_{1}$ diterima.

Jadi terdapat pengaruh interaksi antara model latihan dengan daya ledak otot tungkai terhadap prestasi lompat jauh. (3) Hasil analisis menggunakan Anava yang dilanjutkan dengan uji Tukey menggunakan SPSS 16 diperoleh harga Qhitung = $16,43>Q_{\text {tabel }}=4,00$ (signifikan), maka hipotesis nol ( $\mathrm{Ho})$ diterimadan hipotesis alternatif $(\mathrm{Hi})$ ditolak. maka tidak terdapat perbedaan prestasi lompat jauh antara siswa yang mengikuti model latihan lari kijang untuk siswa yang memiliki tungkai panjang dengan medel latihan lari gawang untuk siswa yang memiliki tungkai tinggi. (4) Hasil analisis menggunakan Anava yang dilanjutkan dengan uji Tukey menggunakan SPSS 
16 diperoleh harga Qhitung $16,43>Q_{\text {tabe }}=4,00$ (signifikan) maka HO ditolak dan HI diterima. Jaditerdapat perbedaan prestasi lompat jauh antara siswa yang mengikuti model latihan lari gawang dan model latihan lari kijang untuk siswa yang memiliki daya ledak otot tungkai rendah.

Berdasarkan temuan tersebut dapat disimpulkan bahwa latihan lari gawang ditinjau dari daya ledak otot tungkai berpengaruh terhadap prestasi lompat jauh pada siswa Kelas VIII SMP Negeri 4 Golewa.

\section{DAFTAR PUSTAKA}

Aip Syarifuddin. 1992. Atletik. Jakarta:

Depertemen Pendidikan dan Kebudayaan

Dantes, Nyoman. 2012. Metode Penelitian.Yogyakarta. CV Andi Offiset.

Departemen Pendidikan Nasional. Kurikulum 2001 SMP. Pendidikan Jasmani.

Depdiknas, 2003. Tes Kesegaran Jasmani Indonesia Untuk Anak Umur 10-12 Tahun. Jakarta : Departemen Pendidikan Nasional RI Eri, Pratikayo. 2010. Tes Pengukuran dan Evaluasi Olahraga. Semarang: Widya Karya. 